\title{
Hagfish feeding habits along a depth gradient inferred from stable isotopes
}

\author{
Vincent Zintzen ${ }^{1, *}$, Karyne M. Rogers ${ }^{2}$, Clive D. Roberts ${ }^{1}$, Andrew L. Stewart ${ }^{1}$, \\ Marti J. Anderson ${ }^{3}$ \\ ${ }^{1}$ Museum of New Zealand Te Papa Tongarewa, 169 Tory Street, Wellington, New Zealand \\ ${ }^{2}$ National Isotope Centre, GNS Science, 30 Gracefield Rd, Gracefield 5010, Lower Hutt 5040, New Zealand \\ ${ }^{3}$ New Zealand Institute for Advanced Study (NZIAS), Massey University, Albany Campus, Auckland, New Zealand
}

\begin{abstract}
Feeding habits of 3 hagfish species were investigated along a depth gradient ( 50 to $900 \mathrm{~m})$ in New Zealand using nitrogen $\left(\delta^{15} \mathrm{~N}\right)$ and carbon $\left(\delta^{13} \mathrm{C}\right)$ stable isotopes. Neomyxine biniplicata had the lowest mean $\delta^{15} \mathrm{~N}$ value $(14.2 \%$ ), followed by Eptatretus cirrhatus $(14.9 \%)$ and Eptatretus sp. 1 (15.8\%). Neomyxine biniplicata ( 50 m depth) was characterized by (1) relative low lipid content in muscles and (2) consistent body condition index which together with its trophic position indicated that this species probably acquires its food by active predation, supplemented by opportunistic scavenging. Eptatretus cirrhatus (48 to $912 \mathrm{~m}$ ) and Eptatretus sp. 1 (290 to $922 \mathrm{~m}$ ) had similar morphology, but their $\delta^{15} \mathrm{~N}$ signature indicated that they were feeding on slightly different trophic levels. For Eptatretus sp. 1, the combination of (1) variable lipid content, indicating phases of feeding and fasting, (2) decreasing body condition index with depth, indicating less regular feeding at depth, (3) increasing $\delta^{15} \mathrm{~N}$ with depth and (4) decreasing $\delta^{13} \mathrm{C}$ signature with depth, pointed towards a feeding behaviour specialized in scavenging on large but rare falls of high-level predators such as whales, sharks or bony fishes. On the other hand, E. cirrhatus was characterized by (1) less variable lipid content, (2) a body condition index not influenced by depth, (3) $\delta^{15} \mathrm{~N}$ values decreasing with depth and $\delta^{13} \mathrm{C}$ values constant across its depth range, which is likely to indicate a more opportunistic and mobile feeding behaviour on a range of prey.
\end{abstract}

KEY WORDS: Fish · Ecology · Nitrogen · Carbon · Body condition index · Lipid content · Eptatretus $\cdot$ Neomyxine

\section{INTRODUCTION}

Investigations of foraging strategies of top predators within ecosystems are an important step towards understanding ecological structure and function for fisheries management. Hagfish (Myxinidae) are an important group of demersal fishes because they are often found in high abundance, and have a growing commercial interest for fisheries and pharmaceutical resources (Downing et al. 1984, Powell et al. 2005, Knapp et al. 2011). Knowledge of their feeding and population ecology will be critical to regulation and sustainable fisheries management.

*Email: vincentz@tepapa.govt.nz
Hagfish have elongated eel-like bodies with a leathery skin and secrete significant amounts of slime that they use as a defence mechanism against predation (Zintzen et al. 2011). They are commonly considered to be scavengers, but acquisition of food by predation has been suspected (Shelton 1978, Martini 1998) and recently observed (Zintzen et al. 2011). Hagfish often burrow in sediments and create bioturbation searching for invertebrate prey (Martini 1998). Stomach content analysis of several species of hagfish has revealed the presence of a large variety of prey, including polychaetes, shrimps, hermit crabs, cephalopods, brittlestars, bony fishes, sharks,

(C) Museum of New Zealand Te Papa Tongarewa and Massey University and GNS Science 2013. Open Access under Creative Commons by Attribution Licence. Use, distribution and reproduction are unrestricted. Author(s) and original publication must be credited. Publisher: Inter-Research · www.int-res.com 
birds and whale flesh (Strahan 1963, Shelton 1978, Johnson 1994, Martini 1998). It is assumed from stomach contents that hagfish food resources are of mesopelagic origin in deeper-living species, but consist primarily of benthic invertebrates for shallowliving species (Martini 1998). This suggests that hagfish from deep waters could preferentially feed on carrion falls, such as carcasses of marine mammals. For example, at $1310 \mathrm{~m}$ depth, Eptatretus deani was observed feeding to satiation on bait fall (Smith 1985). Fishes with scavenging behaviour in the deepsea are often considered to be opportunistic feeders because of the presumed rarity of potential feeding events. However, it is unclear to what extent hagfish are truly non-discriminatory in their food selection. For any given species, the potential degree of prey specificity has not been explored. Variation in prey or feeding strategies within a species and along important environmental gradients, such as depth, has not previously been explored.

Fasting is an important aspect of hagfish feeding strategy. It has been suggested that hagfishes often stay immobile between feeding events, which may be separated by long periods of time, as the probability of nekton fall can be low at depth (Smith \& Baco 2003). A 'sit and wait' behaviour coupled with a low basal energy requirement make them good candidates for prolonged periods of fasting (Martini 1998, Cox et al. 2011, Drazen et al. 2011). One species, Eptatretus stoutii, has reportedly been kept in an aquarium for 9 to 11 mo without food (Tamburri \& Barry 1999). Fasting would be a particularly useful adaptive strategy for species specializing in nekton falls, but would be less important for more opportunistic species, which could also feed on benthic fauna. Fasting fishes tend to use their stored lipids first and to conserve proteins (Weatherley \& Gill 1981, Rueda et al. 1998). As hagfishes stock lipids in their muscles (Flood 1998), it is likely that the lipids are used as a source of energy during fasting periods. Muscle of E. deani, a deep-living species, comprised an average of $34 \%$ lipids (dry weight) but demonstrated quite variable values in percent lipids between individuals (Drazen et al. 2011), indicating that some individuals were fasting while others had recently eaten. The shallower species E. stoutii had much lower and less variable lipid content in their muscle (8\%, Drazen et al. 2011), probably as a result of food being more frequently available at shallower depths.

Carbon and nitrogen stable isotopes are commonly used to study marine trophic relationships and, more recently, feeding patterns and habitats of mobile marine species (Logan \& Lutcavage 2008, Hückstädt et al. 2012). By measuring carbon and nitrogen isotopes, one can gain insights into dietary variation and feeding strategies among species, and among populations from different locations.

Carbon isotopes $\left({ }^{13} \mathrm{C} /{ }^{12} \mathrm{C}\right.$ or $\left.\delta^{13} \mathrm{C}\right)$ integrate information on the origin of resources, from primary production (pelagic vs. benthic) to higher trophic levels (Pinnegar \& Polunin 2000). Heavier isotopes $\left({ }^{13} \mathrm{C}\right.$ ) increase as trophic level increases, with tissues tending to be weakly enriched in the heavier $\left({ }^{13} \mathrm{C}\right)$ carbon isotope at a rate of approximately $\delta^{13} \mathrm{C}<1 \%$ per trophic level (DeNiro \& Epstein 1981).

Nitrogen isotopes $\left({ }^{15} \mathrm{~N} /{ }^{14} \mathrm{~N}\right.$ or $\left.\delta^{15} \mathrm{~N}\right)$ increase with trophic transfer at a rate of 2 to $4 \%$ per trophic level (DeNiro \& Epstein 1981, Peterson \& Fry 1987), generally allowing a clearer assessment of trophic position and feeding niche width than carbon isotopes. In addition, when long periods of fasting occur, individuals will catabolise endogenous amino acids to meet the demands of protein synthesis (Deschner et al. 2012), and consume their own body tissue. The result is ${ }^{15} \mathrm{~N}$ enrichment in the remaining muscle tissue (Hatch et al. 2006).

This study used stable isotopes to investigate the feeding habits of 3 species of Myxinidae found in New Zealand waters (one species of the genus Neomyxine and 2 species of Eptatretus) along a depth gradient of 50 to $\sim 900 \mathrm{~m}$. The 2 Eptatretus species are morphologically very similar, E. cirrhatus being only differentiated from Eptatretus sp. 1 (a recognized but still undescribed species) by having 1 or 2 extra prebranchial slime pores and a white rim around some of its slime pores. We tested the following hypotheses: (1) different but morphologically similar species of hagfish occupy different niches by feeding at different trophic levels, (2) hagfishes at different depths feed on different types of food resources, and (3) hagfishes will show signs of food deprivation in some specimens, as measured by lipid contents and body condition, indicating that they can fast, waiting for the next feeding opportunity

\section{METHODS}

\section{Hagfish collection}

Three species of hagfish, Eptatretus cirrhatus $(\mathrm{n}=$ 34), Eptatretus sp. $1(\mathrm{n}=39)$ and Neomyxine biniplicata $(\mathrm{n}=11)$, were sampled using fish traps deployed at $50,100,300,500,700$ and $900 \mathrm{~m}$ depths at 2 locations in New Zealand waters (Table 1). White Island 
Table 1. Number of hagfish specimens collected per location

\begin{tabular}{|lcc|}
\hline & White Island & Kaikoura \\
\hline Neomyxine biniplicata & 0 & 11 \\
Eptatretus cirrhatus & 30 & 4 \\
Eptatretus sp. 1 & 22 & 17 \\
Total & 52 & 32 \\
\hline
\end{tabular}

$\left(37.5211^{\circ} \mathrm{S}, 177.1821^{\circ} \mathrm{E}\right)$ was sampled in March 2009 and Kaikoura $\left(42.4315^{\circ} \mathrm{S}, 173.7087^{\circ} \mathrm{E}\right)$ was sampled in November 2010. The fish traps were deployed along 5 (White Island) and 3 (Kaikoura) transects running from 50 to $900 \mathrm{~m}$. The fish trap design was circular (diameter: $1.6 \mathrm{~m}$, height: $0.8 \mathrm{~m}$, mesh size: $2 \mathrm{~cm}$ ) and fitted with 3 funnelling entrances tapering from 0.4 to $0.2 \mathrm{~m}$ (square entrance). The bait consisted of $4 \mathrm{~kg}$ of Sardinops sagax that were thawed and chopped prior to being placed into 2 bait bags installed inside the fish traps. Each fish trap was equipped with a sensor (Star Oddi DST centi TD) that measured depth to a precision of 0.4 to $0.6 \%$ of the depth range (e.g. $\pm 1 \mathrm{~m}$ at $50 \mathrm{~m}$ depth and $\pm 9 \mathrm{~m}$ at $1200 \mathrm{~m} \mathrm{depth}$ ). The fish traps were retrieved after 2 to $4 \mathrm{~h}$, and the specimens of hagfish were immediately bagged and frozen at $-20^{\circ} \mathrm{C}$.

\section{Hagfish measurements}

Hagfishes were identified after thawing and cleaning of excess slime. Their length was measured to the nearest $\mathrm{mm}$ as total length (TL, excluding barbels). Specimens were then weighed to the nearest gram. Dorsal muscle thickness was measured using callipers at mid-body length.

\section{Stable isotope sample preparation}

Muscle tissue samples were taken from under the skin at the mid-body dorsal region of each hagfish, freeze dried and ground finely. Due to variable interand intra-species lipid contents in hagfish muscle, chemical lipid extraction of samples is done prior to analysis or values must be corrected using normalisation factors which deduct the lipid contribution from the base tissue value (Logan et al. 2008). Trophic changes in carbon isotopes can be altered or masked by lipids stored in tissues because they incorporate less ${ }^{13} \mathrm{C}$ than the protein fraction of the tissue, due to a kinetic isotope effect (DeNiro \& Epstein 1977). Chemical lipid extraction methods are found to affect the $\delta^{15} \mathrm{~N}$ values of fish tissue (Sweeting et al. 2006, Kolasinski et al. 2009), so samples should be analysed twice to determine accurate $\delta^{13} \mathrm{C}$ (lipid free tissue) and $\delta^{15} \mathrm{~N}$ (non delipidized tissue) values. Chemical lipid extraction of ground muscle samples was done prior to analysis, following the method of Bligh \& Dyer (1959), modified by Hobson et al. (2000), Kolasinski et al. (2009) and Rogers (2009). A portion $(\sim 1 \mathrm{~g})$ of ground muscle was agitated for $1 \mathrm{~h}$ with $30 \mathrm{ml}$ of a 2:1 solution of chloroform:methanol. The delipidized hagfish tissue was separated from the lipids by centrifuging at $3500 \mathrm{rpm}$ for $5 \mathrm{~min}$. The extracted lipids were decanted and the solids resuspended with another $30 \mathrm{ml}$ of a 2:1 mixture of chloroform:methanol, agitated briefly and the centrifuge procedure repeated. This rinsing step was performed another 3 times until the solvent ran clear. The delipidized muscle was oven-dried overnight at $30^{\circ} \mathrm{C}$ to remove any residual solvent. Untreated samples containing lipids are referred to as 'untreated' samples (noted $\delta^{13} \mathrm{C}$ and $\delta^{15} \mathrm{~N}$ ) and delipidized samples as 'extracted' (noted $\delta^{13} \mathrm{C}^{\prime}$ and $\delta^{15} \mathrm{~N}^{\prime}$ ).

\section{Stable isotope analysis}

Carbon and nitrogen content and isotopic composition of the untreated and extracted hagfish were analyzed according to methods described in Kolasinski et al. (2009) and Rogers (2009) at the Stable Isotope Laboratory, GNS Science, New Zealand. Analytical precision of the measurements is $\pm 0.2 \%$, and reproducibility of the results is within $\pm 0.2 \%$ for carbon and $\pm 0.3 \%$ for nitrogen (1 SD).

\section{Lipid content and body condition of hagfishes}

The atomic C:N ratio $(\% \mathrm{C} \times 14 / \% \mathrm{~N} \times 12)$ or $\Delta \delta^{13} \mathrm{C}$ values (with $\Delta \delta^{13} \mathrm{C}=\delta^{13} \mathrm{C}^{\prime}-\delta^{13} \mathrm{C}$ ) can serve as proxies for lipid content in animal tissues because muscle tissues with higher lipid content will have greater negative $\delta^{13} \mathrm{C}$ values (DeNiro \& Epstein 1977). They can also be used to indicate nutritional stress and loss of lipids from tissues due to fasting (Graves et al. 2012). Several equations are available in the literature to evaluate the percentage of lipid in different tissues from $\Delta \delta^{13} \mathrm{C}$ values or bulk C:N ratios (McConnaughey \& McRoy 1979, Kiljunen et al. 2006, Sweeting et al. 2006, Post et al. 2007, Logan et al. 2008). The results we obtained using those equations can be found in Supplement 1 available at www.int- 
res.com/articles/suppl/m485p223_supp.pdf. Due to the inconsistency of those results, it was decided to use $\Delta \delta^{13} \mathrm{C}$ values as a proxy for the lipid content of hagfish muscles in this study.

Lipids in muscles are used as energy storage and their state can give an indication of whether specimens have been feeding recently, or have been in a period of food deprivation. Within any species, specimens with high lipid levels have fed recently (within the last month), whereas specimens with low lipid levels have been using their lipid as an energy source (Tocher 2003).

A body condition index $\left(B_{c}\right)$ was calculated for each specimen after fixation in formalin and preservation in $70 \%$ isopropanol using:

$$
B_{c}=\frac{W}{L} \times 1000
$$

where $W$ is the width (in $\mathrm{mm}$ ) of the dorsal muscle taken at mid-body length and $L$ is the length of the specimen (in $\mathrm{mm}$ ). This index was chosen rather than a mass body index, based on length and weight, due to potential bias introduced when recording weight of specimens with food in their stomach and intestine. The dorsal muscle is the most important one in hagfishes and is responsible for most of their movements and swimming activity. We anticipate that well-fed specimens over an extended period of time (at the scale of a year) will have greater muscle mass which will be mostly accumulated in the dorsal muscle. For each species, $B_{c}$ was scaled from 0 (specimen with the lowest $B_{C}$ value) to 100 (specimen with the highest $B_{c}$ value) to allow meaningful comparisons of values between species.

\section{Data analysis}

The extracted (lipid free) samples for stable carbon $\left(\delta^{13} C^{\prime}\right)$ isotopes and untreated samples for stable nitrogen $\left(\delta^{15} \mathrm{~N}\right)$ isotopes were used for the analysis. An initial permutational multivariate analysis of variance (PERMANOVA) (Anderson 2001) was fitted on the 2 isotopic variables to test for the effect of location (Lo, a fixed factor with 2 levels), species ( $\mathrm{Sp}$, a fixed factor with 3 levels) and depth (De, a continuous variable) as a covariate. The PERMANOVA was done using a Type I (sequential) sum of squares which meant that each term was fitted taking into account all previous terms in the model. Normalised Euclidean distances between hagfish individuals, based on their $\delta^{13} \mathrm{C}^{\prime}$ and $\delta^{15} \mathrm{~N}$ signature, was used as a dissimilarity measure.
Hagfish specimens from the 2 locations (White Island and Kaikoura) were pooled together for the analysis (see Supplement 2). To further investigate the a priori grouping by species based on $\delta^{15} \mathrm{~N}$ and $\delta^{13} \mathrm{C}^{\prime}$ values, a canonical analysis of principle coordinates (CAP) was performed on the data using normalised Euclidean distances between specimens (Anderson \& Willis 2003). In this form, CAP is equivalent to a classical discriminant analysis. Leave-oneout mis-classification error (Lachenbruch \& Mickey 1968) was used to obtain a direct measure of the ability of the CAP discriminant model to identify species on the basis of these 2 stable isotope measures alone. This cross-validation approach provided a rigorous assessment of the distinctiveness of the isotopic signatures for the 3 species.

The effects of species, depth of capture and specimen lengths (a continuous variable) were investigated separately on both $\delta^{13} \mathrm{C}^{\prime}$ and $\delta^{15} \mathrm{~N}$ values using ANCOVA. For each species, the effect of depth on $\delta^{15} \mathrm{~N}, \delta^{13} \mathrm{C}^{\prime}$, lipid content $\left(\Delta \delta^{13} \mathrm{C}\right)$ and body condition $\left(B_{c}\right)$ was then evaluated using linear regression. Multiple comparisons between species were done using Tukey's honestly significant differences (HSD). The effect of $\delta^{15} \mathrm{~N}$ values on lipid content and body condition were also inspected for each species using linear regressions. The distributions of the residuals were inspected to assess the adequacy of linear regression models and did not show any violation of assumptions. Prior to ANCOVA and regressions, data were checked for homogeneity of variances using the Fligner test and approximate normality using Q-Q plots. Finally, correlation between the 3 variables of $\delta^{15} \mathrm{~N}$, lipid content and body condition were investigated to identify any potential signs of food deprivation.

CAP and PERMANOVA analyses were done using PERMANOVA+ (Anderson et al. 2008), the add-on for PRIMER v6 (Clarke \& Gorley 2006) and all other statistical analyses were done using R (R Development Core Team 2012).

\section{RESULTS}

The 3 hagfish species were identifiable as 3 separate groups on the basis of stable carbon and nitrogen values (Fig. 1, Table 2). The PERMANOVA partitioning showed a significant effect of species on $\delta^{13} \mathrm{C}^{\prime}$ and $\delta^{15} \mathrm{~N}$, even after taking into account the effect of location (Table 3). However, a significant interaction between depth and species was still detected, even after fitting the depth by location 


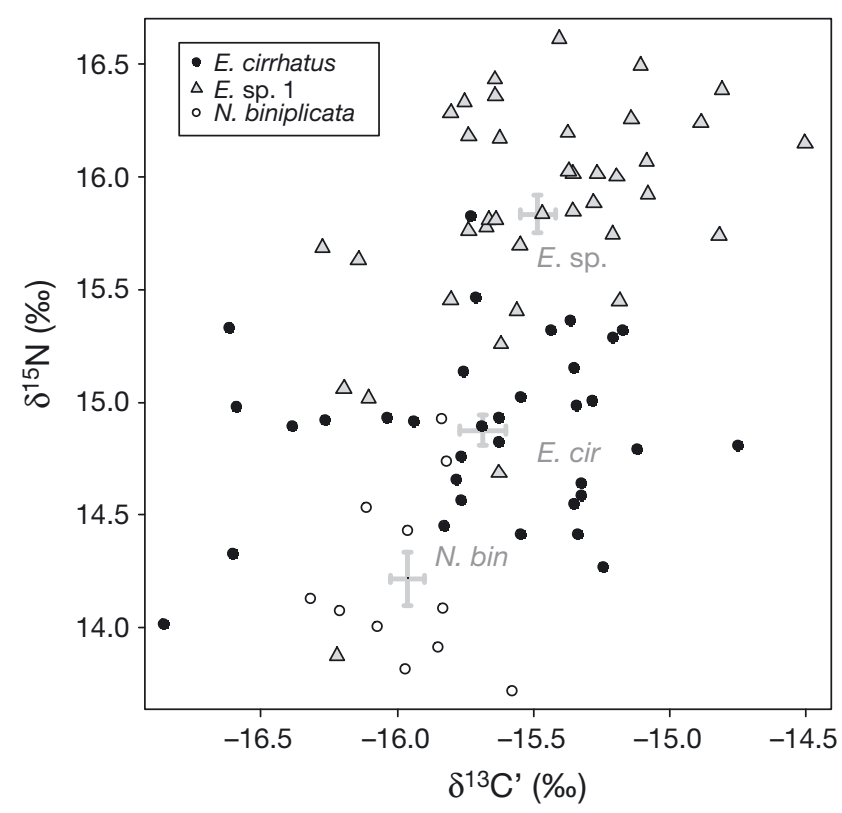

Fig. 1. Eptatretus cirrhatus, Eptatretus sp. 1 and Neomyxine biniplicata. Stable carbon $\left(\delta^{13} C^{\prime}\right)$ and nitrogen $\left(\delta^{15} N\right)$ isotope values for 3 species of hagfish. $\delta^{15} \mathrm{~N}$ values are for untreated muscle samples and $\delta^{13} C^{\prime}$ values are for extracted (lipidfree) samples. Also given are the mean $( \pm 1 \mathrm{SE})$ values for each species

interaction. This means that, even though the depth effects on isotopic signatures depended on the factor location, the depth by species interaction was still significant over and above any variation in the effects of depth from one location to the next. The diagnostics of the CAP analysis showed that, overall, $77 \%$ of the specimens were correctly classified into their respective species using $\delta^{13} \mathrm{C}^{\prime}$ and $\delta^{15} \mathrm{~N}$ information. By species, the percentage of 'left-out' specimens correctly classified by the CAP discriminant model was $73 \%$ for Neomyxine biniplicata, $87 \%$ for Eptatretus sp. 1 and $68 \%$ for E. cirrhatus. Mean $\delta^{13} \mathrm{C}^{\prime}$ values $( \pm \mathrm{SD})$ were broadly similar but $N$. biniplicata differed significantly from Eptatretus sp. 1 (Tukey's HSD test, $\mathrm{p}<0.01)$. N. biniplicata had the lowest mean $\delta^{13} C^{\prime}$ value $(-16.0 \pm 0.2 \%)$, followed by E. cir-
Table 3. PERMANOVA results for the effect of location (fixed, 2 levels), species (fixed, 3 levels) and depth as a covariate on isotope signature $\left(\delta^{13} \mathrm{C}^{\prime}\right.$ and $\left.\delta^{15} \mathrm{~N}\right)$ of hagfishes. Euclidean distances were used on normalised variables, partitioning was done using Type I (sequential) sum of squares and p-values were obtained using 9999 permutations

\begin{tabular}{|lrccc|}
\hline Source & df & MS & Pseudo-F & $p$ \\
\hline Location & 1 & 88.067 & 87.905 & 0.0008 \\
Species & 2 & 30.252 & 30.196 & 0.0001 \\
Depth & 1 & 29.772 & 29.717 & 0.0652 \\
Depth $\times$ Location & 1 & 10.458 & 10.438 & 0.0005 \\
Depth $\times$ Species & 1 & 61.125 & 61.013 & 0.0062 \\
Residual & 77 & 10.018 & & \\
Total & 83 & & & \\
\hline
\end{tabular}

rhatus $(-15.7 \pm 0.5 \%$ o $)$ and Eptatretus sp. $1(-15.5 \pm$ $0.4 \%$ o). $N$. biniplicata also had the lowest mean $\delta^{15} \mathrm{~N}$ value $(14.2 \pm 0.4 \%$ o), followed by E. cirrhatus $(14.9 \pm$ $0.4 \%$ ) and Eptatretus sp. 1 (15.8 $\pm 0.5 \%$ o). Stable nitrogen values also differed significantly between every pair of species (Tukey's HSD tests, $\mathrm{p}<0.001$ ).

Although hagfish length did not explain significant variation in either of the stable isotopes, a significant interaction between depth and species was detected for $\delta^{15} \mathrm{~N}$ and also for $\delta^{13} \mathrm{C}^{\prime}$ values (Table 4). Neomyxine biniplicata was restricted to $50 \mathrm{~m}$ depth, while Eptatretus cirrhatus was sampled along the entire depth range (48 to $912 \mathrm{~m}$ ) and Eptatretus sp. 1 occurred from 290 to $922 \mathrm{~m}$. $\delta^{15} \mathrm{~N}$ values significantly decreased with depth for $E$. cirrhatus (linear regression, $\mathrm{p}<0.05)$ and significantly increased with depth for Eptatretus sp. 1 ( $\mathrm{p}<0.01$, Fig. 2A). This suggested that captured specimens of $E$. cirrhatus were feeding on lower trophic levels at deeper depths, while specimens of Eptatretus sp. 1 were either feeding on higher trophic levels or fasting at deeper depths. The variation around the mean $\delta^{15} \mathrm{~N}$ value was slightly higher for Eptatretus sp. 1 than for E. cirrhatus, indicating that Eptatretus sp. 1 was feeding on a wider range of prey than E. cirrhatus.

Carbon isotopes indicated that Neomyxine biniplicata was feeding on prey whose carbon was of a less

Table 2. Eptatretus cirrhatus, Eptatretus sp. 1 and Neomyxine biniplicata. Mean $( \pm \mathrm{SD})$ stable carbon and nitrogen isotope values from muscles of each of 3 species of hagfish, either before (untreated) or after chemical lipid extraction. $\mathrm{C}: \mathrm{N}$ indicates the atomic $\mathrm{C}: \mathrm{N}$ ratio $(\% \mathrm{C} \times 14 / \% \mathrm{~N} \times 12) . \Delta \delta^{13} \mathrm{C}$ is the difference between $\delta^{13} \mathrm{C}^{\prime}$ and $\delta^{13} \mathrm{C}$ values

\begin{tabular}{|c|c|c|c|c|c|c|c|c|c|c|}
\hline \multirow[t]{2}{*}{ Species } & \multirow[t]{2}{*}{$\mathrm{n}$} & \multirow{2}{*}{$\begin{array}{l}\text { Depth } \\
\text { (m) }\end{array}$} & \multirow{2}{*}{$\begin{array}{l}\text { Length } \\
(\mathrm{mm})\end{array}$} & \multicolumn{3}{|c|}{ Untreated - } & \multicolumn{3}{|c|}{ L Lipid-extracted } & \multirow{2}{*}{$\begin{array}{c}\Delta \delta^{13} \mathrm{C} \\
(\% \circ)\end{array}$} \\
\hline & & & & $\delta^{13} \mathrm{C}(\%)$ & $\delta^{15} \mathrm{~N}(\%)$ & $C: N$ & $\delta^{13} \mathrm{C}^{\prime}(\%)$ & $\delta^{15} \mathrm{~N}^{\prime}(\%)$ & $C: N$ & \\
\hline N. biniplicata & 11 & 63 & $278-410$ & $-17.7 \pm 0.3$ & $14.2 \pm 0.4$ & $5.6 \pm 0.4$ & $-16.0 \pm 0.2$ & $15.1 \pm 0.4$ & $3.7 \pm 0.1$ & $1.8 \pm 0.3$ \\
\hline Eptatretus sp. 1 & 39 & $290-922$ & $379-716$ & $-20.4 \pm 0.7$ & $15.8 \pm 0.5$ & $13.0 \pm 0.7$ & $-15.5 \pm 0.4$ & $16.9 \pm 0.5$ & $3.8 \pm 0.1$ & $4.9 \pm 0.8$ \\
\hline
\end{tabular}


Table 4. Eptatretus cirrhatus, Eptatretus sp. 1 and Neomyxine biniplicata. Analysis of covariance showing the effect of hagfish species $\left(\mathrm{Sp}_{\text {; }}\right.$ categorical with 3 levels), depth (De; as a continuous variable) and length (Le; also as a continuous variable) of specimens on each of $\delta^{15} \mathrm{~N}$ and $\delta^{13} \mathrm{C}^{\prime}$, as indicated. p-values $<0.05$ are shown in bold

\begin{tabular}{|c|c|c|c|c|c|c|c|c|}
\hline \multirow{2}{*}{ Source } & \multicolumn{4}{|c|}{$\delta^{15} \mathrm{~N}$} & \multicolumn{4}{|c|}{$\delta^{13} C^{\prime}$} \\
\hline & $\mathrm{df}$ & MS & $F$-value & $\mathrm{p}$ & $\mathrm{df}$ & MS & $F$-value & $\mathrm{p}$ \\
\hline Species & 2 & 14.916 & 80.663 & $<0.001$ & 2 & 1.068 & 6.388 & 0.003 \\
\hline Length & 1 & 0.097 & 0.523 & 0.471 & 1 & 0.265 & 1.585 & 0.212 \\
\hline Depth & 1 & 0.001 & 0.006 & 0.94 & 1 & 0.001 & 0.001 & 0.977 \\
\hline $\mathrm{Sp} \times \mathrm{Le}$ & 2 & 0.103 & 0.557 & 0.575 & 2 & 0.236 & 1.412 & 0.25 \\
\hline $\mathrm{Sp} \times \mathrm{De}$ & 1 & 2.776 & 15.012 & $<0.001$ & 1 & 0.927 & 5.544 & 0.021 \\
\hline Le $\times$ De & 1 & 0.105 & 0.566 & 0.454 & 1 & 0.263 & 1.575 & 0.213 \\
\hline $\mathrm{Sp} \times \mathrm{Le} \times \mathrm{De}$ & 1 & 0.326 & 1.762 & 0.188 & 1 & 0.401 & 2.399 & 0.126 \\
\hline Residuals & 74 & 13.684 & 0.185 & 0.185 & 74 & 0.167 & & \\
\hline
\end{tabular}

benthic (or more pelagic) origin (lower mean $\delta^{13} \mathrm{C}^{\prime}$ values), although the differences between the 2 Eptatretus species were small (less than $0.5 \%$ on average). The $\delta^{13} \mathrm{C}^{\prime}$ values for $E$. cirrhatus did not change with depth (Fig. 2B, linear regression, $\mathrm{p}=$ $0.23)$. However, $\delta^{13} C^{\prime}$ values of Eptatretus sp. 1 showed a weak but significant positive relationship with depth $(\mathrm{p}<0.05)$. Thus, specimens of Eptatretus sp. 1 caught at deeper stations were sourcing their carbon from a more benthic origin than those caught at shallower depths.
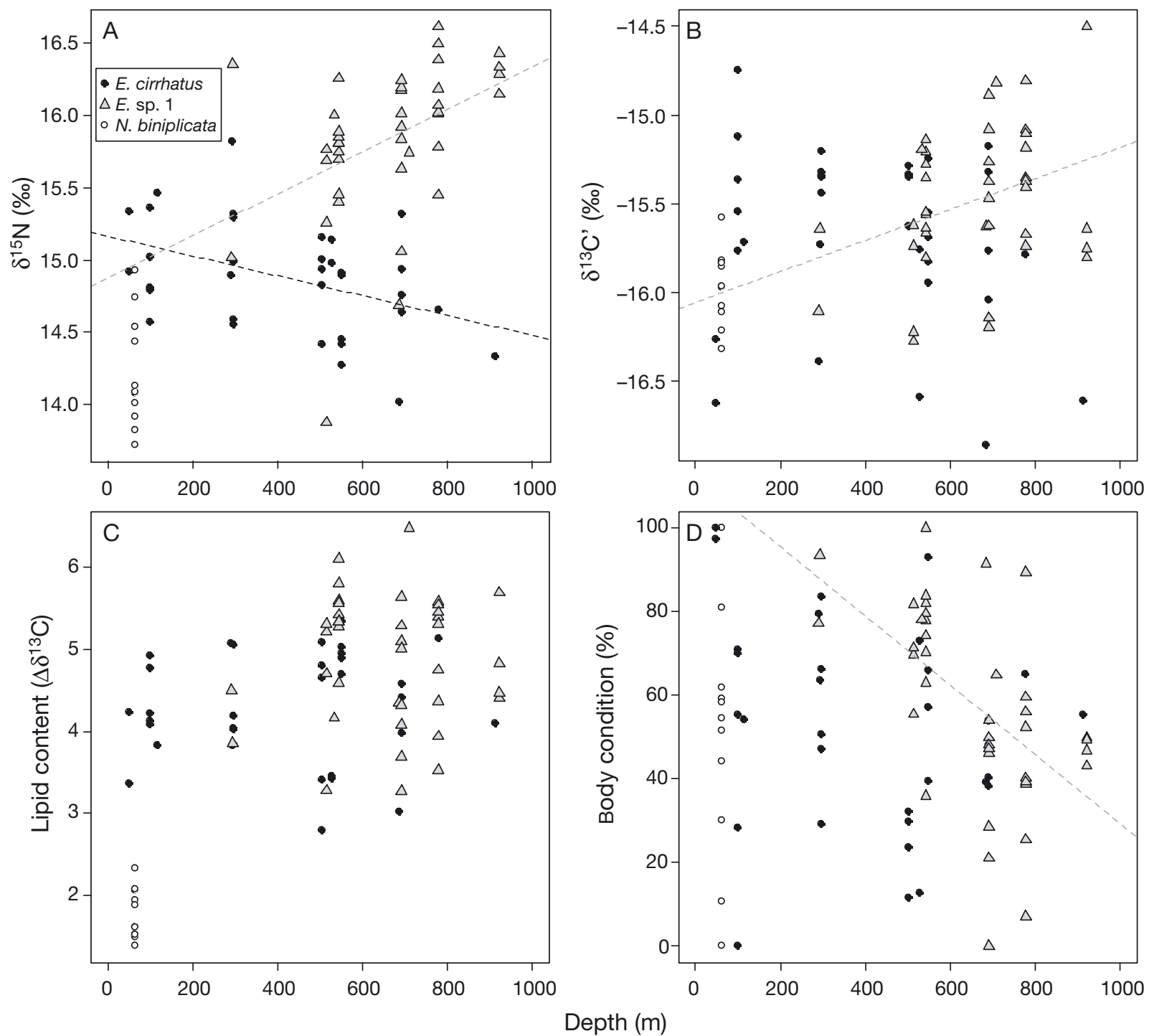

Fig. 2. Eptatretus cirrhatus, Eptatretus sp. 1 and Neomyxine biniplicata. Effect of depth on (A) stable nitrogen isotope values $\left(\delta^{15} \mathrm{~N}\right)$, (B) stable carbon isotope values $\left(\delta^{13} \mathrm{C}^{\prime}\right)$, (C) lipid content in muscles $\left(\Delta \delta^{13} \mathrm{C}\right)$ and (D) body condition index in 3 hagfish species. Only significant regression lines $(\mathrm{p}<0.05)$ are shown: black lines are for E. cirrhatus and gray lines for Eptatretus sp. 1 
The mean estimate for lipid content $\left(\Delta \delta^{13} \mathrm{C}\right)$ of Eptatretus cirrhatus and Eptatretus sp. 1 did not change overall with depth (linear regression, $p=0.48$ and $\mathrm{p}=0.91$, respectively, Fig. 2C). However, the variation in lipid content around the mean was lower at shallow depths (50 to $300 \mathrm{~m}$ ), indicating that those specimens were feeding regularly (i.e. no part of this population was either overfed or starving). At greater depth, the variation in lipid content of E. cirrhatus increased, indicating that some specimens had recently fed while others were consuming their stored lipids. Variation in the mean lipid content of muscles for Eptatretus sp. 1 was larger than for E. cirrhatus.

There was no effect of depth on the body condition index for Eptatretus cirrhatus, but variation around the mean was higher at shallow than at deeper depths (Fig. 2D). The body condition index significantly decreased with depth for Eptatretus sp. 1 (linear regression, $\mathrm{p}<0.001)$. Eptatretus sp. 1 had less muscle tissue at depth than in shallow water. However, there was large variation in body condition values at all depths except for 300 and $900 \mathrm{~m}$.

The range in the untreated C:N ratio varied considerably between individuals: 4.2 to 7.6 (mean $=5.6$ ) for Neomyxine biniplicata, 6.1 to $24.9($ mean $=11.1)$ for Eptatretus cirrhatus and 6.7 to 24.6 (mean = 13.0) for Eptatretus sp. 1 (Table 2). After lipid extraction, C:N ratios of the 3 studied species were all comparable to each other with mean $( \pm \mathrm{SD})$ values of $3.7 \pm 0.1$ for $N$. biniplicata, $3.8 \pm 0.1$ for E. cirrhatus and $3.8 \pm 0.1$ for Eptatretus sp. 1 (Table 2). There was a strong relationship between bulk C:N ratios and $\Delta \delta^{13} \mathrm{C}$ (Fig. 3). Estimates for the lipid content of hagfish muscle $\left(\Delta \delta^{13} \mathrm{C}\right)$ ranged from 1.38 to 6.48 . N. biniplicata had significantly lower muscle lipid content (mean $\pm \mathrm{SD} \Delta \delta^{13} \mathrm{C}=1.76 \pm 0.09 \%$, $t$-test $\mathrm{p}<0.001$ ) than the 2 Eptatretus species (E. cirrhatus: $\Delta \delta^{13} \mathrm{C}=$ $4.31 \pm 0.12 \%$; Eptatretus sp. $1: \Delta \delta^{13} \mathrm{C}=4.89 \pm 0.13 \%$ ) , which were also significantly different from each other for that parameter (Fig. 2C, 2-sample $t$-test, $\mathrm{p}<$ 0.001).

There was a clear and positive relationship between lipid content in hagfish muscles and $\delta^{15} \mathrm{~N}$ values (Fig. 4A, linear regression, $\mathrm{p}=0.001$ ). Species feeding at higher trophic levels accumulated more lipids in their muscle than did those feeding at lower trophic levels. Although this pattern held when combining all species of hagfish together, it was not observed when looking at species individually and there was even an opposite trend for Eptatretus cirrhatus, which had increasing $\delta^{15} \mathrm{~N}$ values with decreasing lipid content (linear regression, $\mathrm{p}<0.001-$

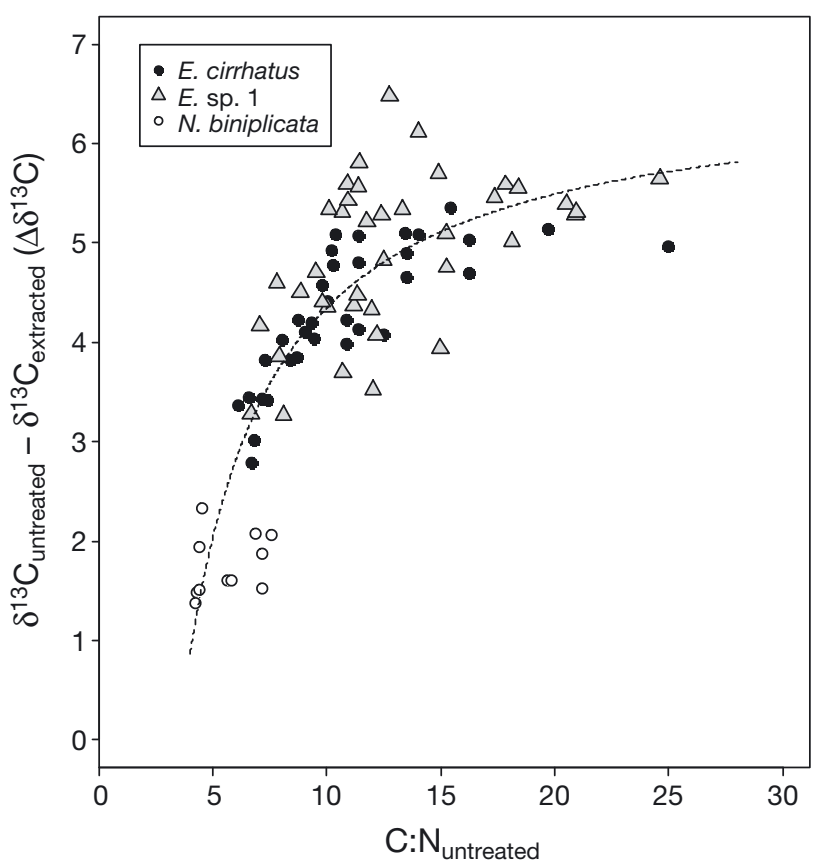

Fig. 3. Eptatretus cirrhatus, Eptatretus sp. 1 and Neomyxine biniplicata. Relationship between C:N ratios of untreated samples and stable carbon isotopic values of the lipid fraction from hagfish muscles. $\delta^{13} \mathrm{C}$ and $\delta^{13} \mathrm{C}^{\prime}$ values are for the untreated and extracted (lipid-free) samples, respectively. $\mathrm{C}: \mathrm{N}$ ratios are from untreated samples. The regression line is from the lipid-normalization model of McConnaughey \& McRoy (1979), where the constants have been estimated by iterative non-linear least square regression to be $D=7.692$ and $I=-0.093$

omitting one outlier which was the only individual having both a relatively low lipid content and a low $\delta^{15} \mathrm{~N}$ value).

The body condition index had no clear relationship with either $\delta^{15} \mathrm{~N}$ values (Fig. 4B) or the lipid content (Fig. 5). For Neomyxine biniplicata, there was a trend for specimens with high body condition index to feed at a higher trophic level (Fig. 5A). There was no significant relationship detected between lipid content and either body condition or trophic level, although this could be due to the low number of $N$. biniplicata specimens available. For Eptatretus cirrhatus, 26, 50 and $24 \%$ of the specimens had a body condition index ranging from $0-33,34-66$ and $67-100 \%$, respectively (Fig. $5 \mathrm{~B}$, as indicated by the proportion of specimens between the different dotted lines). The specimens with low lipid content and a low body condition index ('skinny') had intermediate values for $\delta^{15} \mathrm{~N}$, as did the lipid-rich specimens with a high body condition index ('fat'). Specimens with intermediate lipid content generally fed on organisms from a higher trophic level, and this was particularly visible for specimens having also an intermediate body con- 

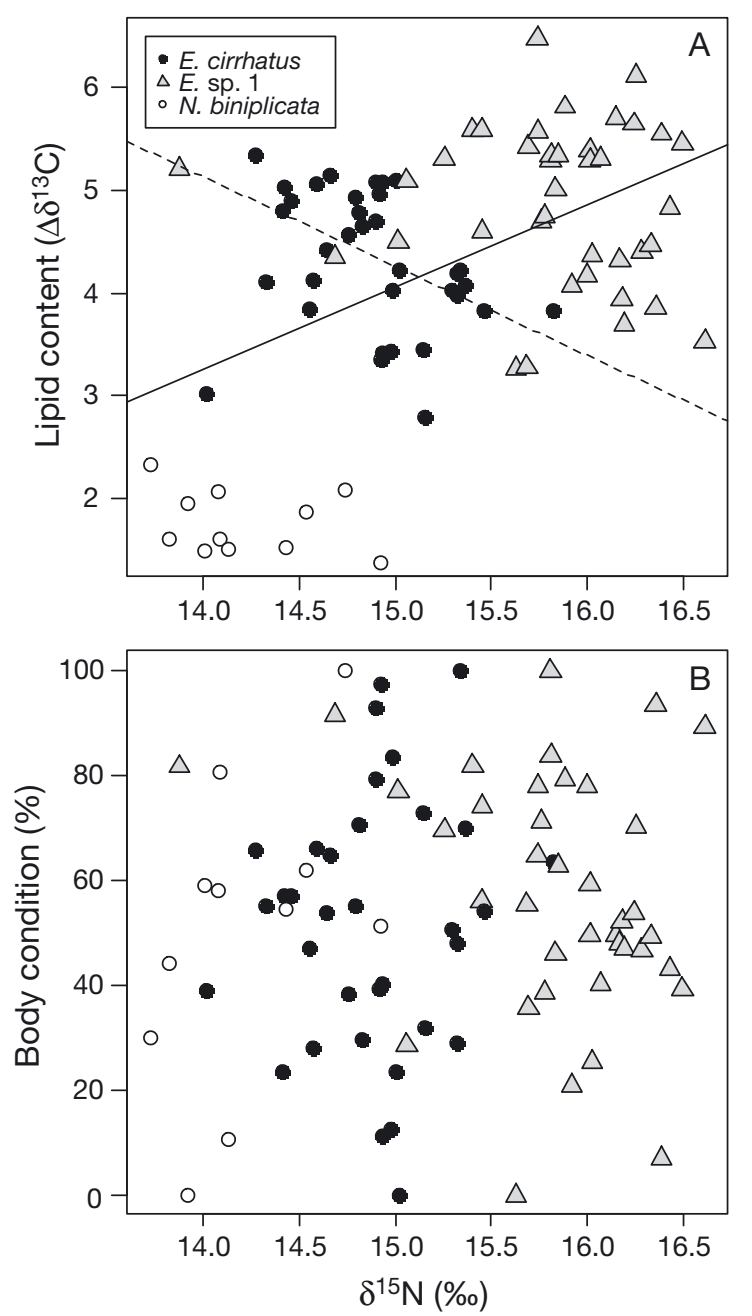

Fig. 4. Eptatretus Cirrhatus, Eptatretus sp. 1 and Neomyxine biniplicata. Effect of stable nitrogen isotope values $\left(\delta^{15} \mathrm{~N}\right)$ on (A) lipid content in muscles $\left(\Delta \delta^{13} \mathrm{C}\right)$ and (B) body condition index in 3 hagfish species. Only significant regression lines $(\mathrm{p}<0.05)$ are shown. The dotted regression line is for

E. cirrhatus and the plain line is for all species combined

Fig. 5. Eptatretus cirrhatus, Eptatretus sp. 1 and Neomyxine biniplicata. Relationship between lipid content in muscles and body condition index for each of 3 species of hagfishes. Superimposed as bubbles on the plot is the trophic level for each individual (as indicated by their $\delta^{15} \mathrm{~N}$ values); bubbles are scaled for each species from 0 (specimen feeding on the lowest trophic level, low $\delta^{15} \mathrm{~N}$ values; no bubble) to 100 (specimen feeding on the highest trophic level, high $\delta^{15} \mathrm{~N}$ values; largest bubbles). The dotted lines arbitrarily divide the ordered data in each scatter-plot into 9 equal-area zones based on the level of lipid content and body condition values (low, medium and high, respectively). Certain zones are qualified as comprising 'skinny' or 'fat' individuals (by reference to their relative body condition index), and comprising 'lipid rich' or 'lipid poor' individuals (by reference to their relative lipid content). (A) N. biniplicata, (B) E. cirrhatus, (C) Eptatretus sp. 1
Neomyxine biniplicata

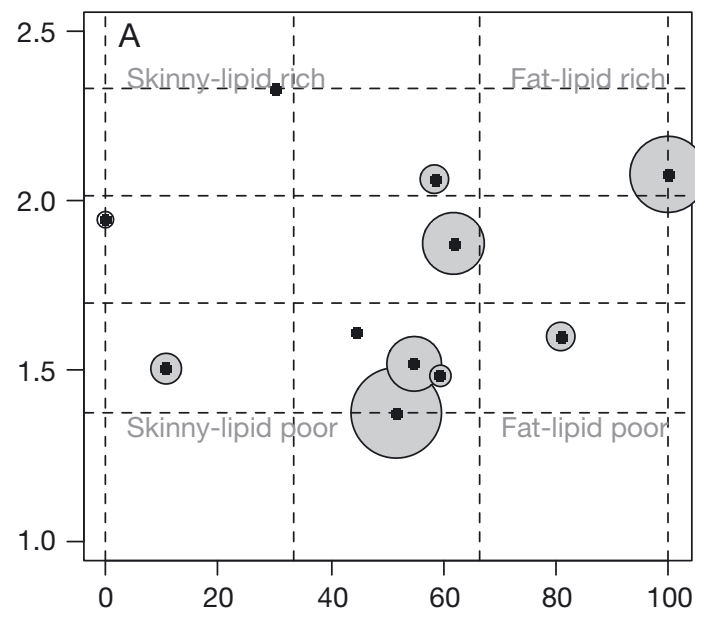

Eptatretus cirrhatus

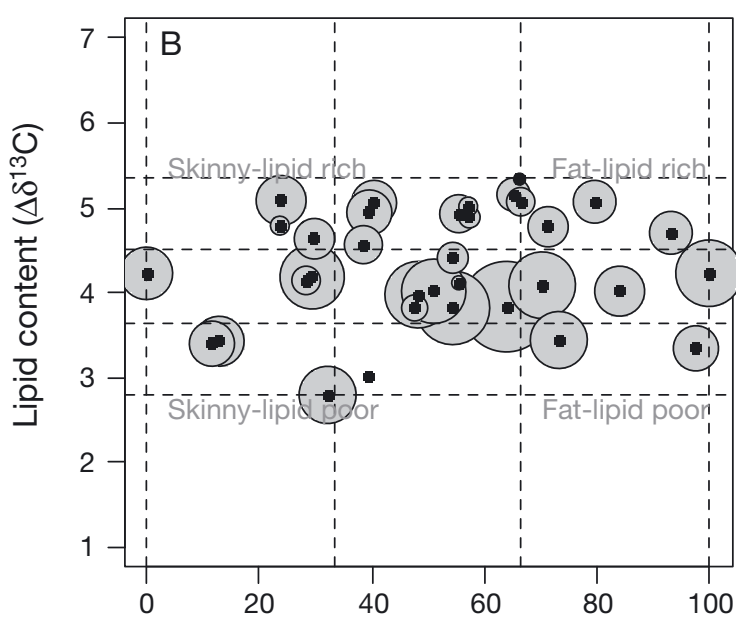

Eptatretus sp. 1

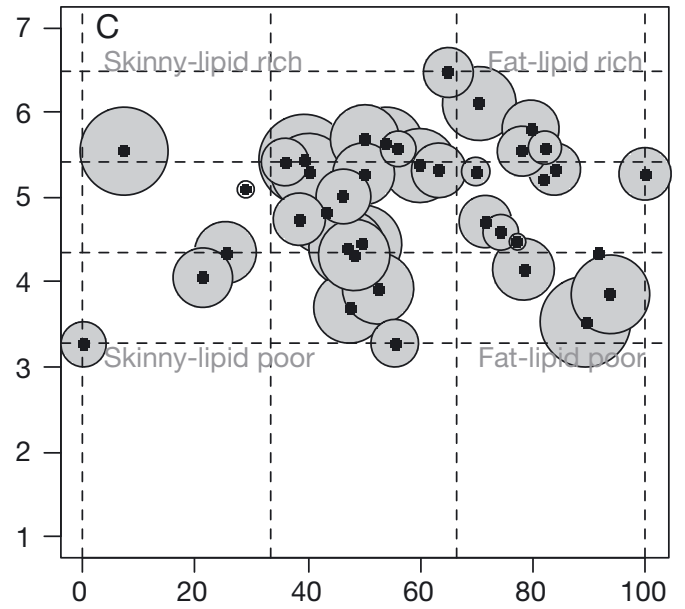

Body condition (\%) 
dition index. In general, specimens which had a higher lipid content fed at a relatively low trophic level but this had no apparent impact on the body condition index. For Eptatretus sp. 1, 13, 49 and $38 \%$ of the specimens had a body condition index ranging from $0-33,34-66$ and $67-100 \%$, respectively (Fig. 5C). The largest fraction of the specimens had an intermediate lipid content and body condition index. There were a few specimens that were both lipid-rich and had a low body condition index. For this species, there were no clear patterns in the distribution of $\delta^{15} \mathrm{~N}$ values in relation to the body condition index or lipid content.

\section{DISCUSSION}

Assessment of the stable isotopes, body condition and lipid content of tissues of New Zealand hagfishes Neomyxine biniplicata, Eptatretus cirrhatus and Eptatretus sp. 1 indicate that they feed consistently on higher trophic levels ( $\delta^{15} \mathrm{~N}$ values: 13.7 to $16.6 \%$ ) when compared to other marine species found in New Zealand (Table 5); it is likely that the 3 hagfish species from this study generally feed 1 to 3 trophic levels above primary consumers (i.e. TL3 to TL5). N. biniplicata had the lowest $\delta^{15} \mathrm{~N}$ values. This species is relatively small with a slender body (Richardson \& Jowett $1951)$ and is very active when observed using baited underwater video (Zintzen et al. 2012). Stable isotopes suggest that this species employs an active feeding strategy, consuming small carrion and also actively preying on invertebrates from soft sediments. A closely associated species, Neomyxine sp. 1, was also observed actively hunting live Cepola haastii, a benthic fish species (Zintzen et al. 2011).
The stable nitrogen isotope values confirm that Neomyxine biniplicata feeds relatively high up the trophic chain, although maybe not so high as to scavenge preferentially on carrion from apex predators. The lipid fraction in its muscle was low compared to the other 2 species which could indicate that this species has low nutritional stress and regularly feeds, actively preying on lipid-poor benthic prey such as invertebrates. Eptatretus cirrhatus was feeding at a slightly higher trophic level than $N$. biniplicata, but at a lower level than Eptatretus sp. 1. The 2 Eptatretus species are morphologically very similar and sympatric, having been recognized as separate species only recently (V. Zintzen pers. obs.). Nonetheless, evidence here suggests that they may occupy a slightly different niche by specializing on different types of prey. The known depth range for E. cirrhatus in New Zealand waters is 1 to $922 \mathrm{~m}$ although it is more common at 90 to $700 \mathrm{~m}$. Eptatretus sp. 1 is found from 290 to $922 \mathrm{~m}$, but is more regularly caught deeper than $500 \mathrm{~m}$ (Te Papa Museum database). $\delta^{15} \mathrm{~N}$ values decrease with depth for $E$. cirrhatus; perhaps Eptatretus sp. 1 has a competitive advantage over E. cirrhatus when feeding at deeper sites, where a larger fraction of the food resource is likely to come from carrion falls. It is also possible that E. cirrhatus tends to consume a greater proportion of benthic prey from lower trophic levels, leading to lower $\delta^{15} \mathrm{~N}$ values for this species. This hypothesis is supported by the values of $\delta^{13} \mathrm{C}^{\prime}$ remaining fairly constant with depth for E. cirrhatus, indicating similarity of carbon sources for its prey across this depth range. If $E$. cirrhatus mostly feeds on carrion from large megafauna at deeper depths, this would be reflected in its $\delta^{13} \mathrm{C}^{\prime}$ values because these animals would presumably have a range of

Table 5. Stable nitrogen and carbon isotope results from present and past studies in New Zealand marine waters

\begin{tabular}{|c|c|c|c|c|}
\hline Species & Trophic position & $\delta^{15} \mathrm{~N}(\%)$ & $\delta^{13} \mathrm{C}(\%)$ & Source \\
\hline Zostera capricorni (Seagrass) & Primary producer & 5.4 & -16.0 to -12.2 & Alfaro et al. (2006) \\
\hline Pecten novaezelandiae (Scallop) & Filter feeder & 8.1 to 9.1 & -19.2 to -16.6 & Forrest et al. (2007) \\
\hline Perna canaliculus (Mussel) & Filter feeder & 9.2 to 11.0 & -18.9 to -18.0 & Forrest et al. (2007) \\
\hline Atrina zelandica (Mussel) & Filter feeder & 9.2 to 10.5 & -18.2 to -17.5 & Forrest et al. (2007) \\
\hline Eptatretus cirrhatus (Hagfish) & Scavenger & -2.8 to 15.5 & -29.2 to -16.7 & McLeod \& Wing (2007) \\
\hline Forsterygion sp. (Fish) & Predator on invertebrates & 12.5 & -16.5 & Alfaro et al. (2006) \\
\hline Parapercis colias (Fish) & Benthic predator & 7.5 to 14.7 & -25.7 to $-16.6^{\mathrm{a}}$ & Rodgers \& Wing (2008) \\
\hline Carcharodon carcharias (Shark) & Top predator & 15.6 & n.a. & K. Rogers (pers. comm.) \\
\hline Tursiops sp. (Dolphin) & Top predator & 12.8 to 15.9 & -16.6 to -13.7 & Lusseau \& Wing (2006) \\
\hline Neomyxine biniplicata (Fish) & Opportunistic feeder & 13.7 to 14.9 & -16.3 to $-15.6^{\mathrm{a}}$ & Present study \\
\hline Eptatretus cirrhatus (Fish) & Opportunistic feeder & 14.0 to 15.8 & -16.9 to $-14.8^{\mathrm{a}}$ & Present study \\
\hline Eptatretus sp. 1 (Fish) & Opportunistic feeder & 13.9 to 16.6 & -16.3 to $-14.5^{\mathrm{a}}$ & Present study \\
\hline
\end{tabular}


carbon isotopic signatures due to their higher mobility. Our results did not show this. Eptatretus sp. 1 showed increasing $\delta^{13} \mathrm{C}^{\prime}$ values with depth. This could indicate a higher reliance on prey which had obtained their carbon from a different, more benthic, pathway. Sperm whales Physeter macrocephalus are common in the canyons off Kaikoura and could represent a source of food, primarily for Eptatretus sp. 1. These cetaceans are apex predators, their diet consisting mostly of cephalopods and fishes (Gaskin \& Cawthorn 1967, Evans \& Hindell 2004, Gómez-Villota 2007) and they have mostly been sighted in water deeper than $500 \mathrm{~m}$ and never shallower than $200 \mathrm{~m}$ (Jaquet et al. 2000). Considering the importance of scavenging on epipelagic prey versus benthic prey, Drazen et al. (2008) found that 2 deep-sea macrourids (4100 m depth) bypassed the benthic food web by consuming relatively large amounts of epipelagic taxa, supplemented by benthic prey. As a result, the macrourids displayed intermediate $\delta^{15} \mathrm{~N}$ values because benthic prey had high stable isotope values for nitrogen compared to epipelagic fishes. If benthic prey display a general increase in $\delta^{15} \mathrm{~N}$ values with depth, then the interpretation of our results is not so straightforward. In this case, the increase of $\delta^{15} \mathrm{~N}$ and $\delta^{13} \mathrm{C}^{\prime}$ values with depth for Eptatretus sp. 1 could simply be explained by a diet containing an increased amount of benthic prey. The analysis of $\delta^{15} \mathrm{~N}$ from additional taxa in this food web or the use of compound-specific nitrogen isotope analysis of individual amino acids (Choy et al. 2012) could improve our understanding of these patterns.

For both Eptatretus species, the lipid content in muscle was high compared to other values for fishes from the literature (e.g. Hoffman \& Sutton 2010) and did not change with depth, but Eptatretus sp. 1 had slightly more variable values, suggesting some nutritional stress. High but variable lipid content in muscle tissue has previously been observed in E. deani, a deep-living species (Drazen et al. 2011). A possible explanation for this variability is that deep-living hagfish individuals are using their lipid reserve between feeding opportunities, so that at any one time, intraspecific variability in lipid content will reflect time lapsed since the last meal. This strategy is again in line with the hypothesis that Eptatretus sp. 1 would be a deeper living species relying on less frequent meals. Another explanation is that lipid content varies with the type of prey the hagfish recently fed on. Our results clearly show a positive relationship between trophic level and lipid content which supports the idea that diet affects lipid metabolism
(Bailey \& Robison 1986). This relationship only holds at the interspecific level, however, not within a species. For E. cirrhatus, there is an increase in $\delta^{15} \mathrm{~N}$ values with decreasing lipid content which was not observed with Eptatretus sp. 1. Previously it has been shown that fasting or nutritional stress can cause elevated $\delta^{15} \mathrm{~N}$ values in tissue (Hobson et al. 1993, GayeSiessegger et al. 2004), due to a faster recycling of the lighter ${ }^{14} \mathrm{~N}$ isotope. It suggests that $E$. cirrhatus has a reduced capacity compared to Eptatretus sp. 1 to sustain periods of fasting and more quickly enters a starvation mode where proteins are preferentially used as an energy source.

Several authors have linked $\Delta \delta^{13} \mathrm{C}$ and C:N ratios to lipid content (see Supplement 1). The maximum hagfish C:N ratio in this study was 24.9 (mean value of 11.2) which is extremely high compared to what has been observed in other fishes (Kiljunen et al. 2006, Hoffman \& Sutton 2010). Glycogen granules have been identified as 'abundant' within the ultrastructure of muscle fibres in hagfish (Mellgren \& Mathisen 1966, Korneliussen \& Nicolaysen 1973). Glycogen comprises very little nitrogen, so it is possible that the high $\mathrm{C}: \mathrm{N}$ ratios observed in this study could also be due to high levels of this compound. Lipids could be used to add buoyancy or as an energy source between periods of feeding for scavengers (Drazen 2007). However, hagfish starved for 1 mo consumed more than $90 \%$ of their glycogen in the liver and skeletal muscle, whereas protein and triglyceride contents appeared less affected (Emdin 1982). These results suggest that fasting for more than 1 mo is necessary for the hagfish to start using its lipid reserve. In light of the high variability in lipid content observed in this study, it is possible that several specimens had been fasting for an extended period of time, possibly several months or more.

This study reports for the first time stable carbon and nitrogen isotope results for hagfishes along a depth gradient. We have found that sympatric and morphologically similar species apparently feed at slightly different trophic levels, and that certain species are actively preying on alternative resources. Although they were first described as opportunistic scavengers, hagfish present some degree of specialization in their foraging and feeding strategies which may provide important information for fisheries management. Phylogenetic research might provide further insights regarding causes of speciation for hagfishes and the potential role of niche differentiation in feeding preferences and strategies along depth gradients in the evolution of the Myxinidae. 
Acknowledgements. The MV 'Tranquil Image' crew N. Furley, G. Gibbs and S. Kelly helped to organize all of the fieldwork using baited fish traps. R. Crech'riou, A. Smith, C. Bedford, O. Hannaford, K. Rodgers, C. Struthers and T. Schultz contributed to the sampling effort. J. Barker helped with the sorting of specimens. We thank the staff of the Stable Isotope Laboratory, National Isotope Centre, GNS Science in Lower Hutt, New Zealand for isotope analysis. This work was supported by a Royal Society of New Zealand Marsden grant (MAU0713), Te Papa Collection Development Programme (AP3126) and FRST/NIWA Marine Biodiversity and Biosecurity OBI (contract COIX0502).

\section{LITERATURE CITED}

Alfaro AC, Thomas F, Sergent L, Duxbury M (2006) Identification of trophic interactions within an estuarine food web (northern New Zealand) using fatty acid biomarkers and stable isotopes. Estuar Coast Shelf Sci 70:271-286

Anderson MJ (2001) A new method for non-parametric multivariate analysis of variance. Austral Ecol 26:32-46

> Anderson MJ, Willis TJ (2003) Canonical analysis of principal coordinates: a useful method of constrained ordination for ecology. Ecology 84:511-525

Anderson MJ, Gorley RN, Clarke KR (2008) PERMANOVA+ for PRIMER: guide to Software and Statistical Methods. PRIMER-E, Plymouth

Bailey TG, Robison BH (1986) Food availability as a selective factor on the chemical-compositions of midwater fishes in the eastern North Pacific. Mar Biol 91:131-141

Bligh EG, Dyer WJ (1959) A rapid method of total lipid extraction and purification. Can J Biochem Physiol 37: 911-917

Choy CA, Davison PC, Drazen JC, Flynn A and others (2012) Global trophic position comparison of two dominant mesopelagic fish families (Myctophidae, Stomiidae) using amino acid nitrogen isotopic analyses. PLoS ONE 7:e50133

Clarke KR, Gorley RN (2006) PRIMER v6: user manual/ Tutorial. PRIMER-E, Plymouth, UK

> Cox GK, Sandblom E, Richards J, Farrell A (2011) Anoxic survival of the Pacific hagfish Eptatretus stoutii. J Comp Physiol B 181:361-371

DeNiro MJ, Epstein S (1977) Mechanism of carbon isotope fractionation associated with lipid synthesis. Science 197 : 261-263

$>$ DeNiro MJ, Epstein S (1981) Influence of diet on the distribution of nitrogen isotopes in animals. Geochim Cosmochim Acta 45:341-351

> Deschner T, Fuller BT, Oelze VM, Boesch C and others (2012) Identification of energy consumption and nutritional stress by isotopic and elemental analysis of urine in bonobos (Pan paniscus). Rapid Commun Mass Spectrom 26:69-77

> Downing SW, Spitzer RH, Koch EA, Salo WL (1984) The hagfish slime gland thread cell. I. A unique cellular system for the study of intermediate filaments and intermediate filament-microtubule interactions. J Cell Biol 98: 653-669

> Drazen JC (2007) Depth related trends in proximate composition of demersal fishes in the eastern North Pacific. Deep-Sea Res I 54:203-219

> Drazen JC, Popp BN, Choy CA, Clemente T, De Forest L, Smith KL (2008) Bypassing the abyssal benthic food web:
Macrourid diet in the eastern North Pacific inferred from stomach content and stable isotopes analyses. Limnol Oceanogr 53:2644-2654

> Drazen JC, Yeh J, Friedman J, Condon N (2011) Metabolism and enzyme activities of hagfish from shallow and deep water of the Pacific Ocean. Comp Biochem Physiol A Mol Integr Physiol 159:182-187

Emdin SO (1982) Effects of hagfish insulin in the atlantic hagfish, Myxine glutinosa - the in vivo metabolism of $\left[{ }^{14} \mathrm{C}\right]$ glucose and $\left[{ }^{14} \mathrm{C}\right]$ leucine and studies on starvation and glucose-loading. Gen Comp Endocrinol 47:414-425

> Evans K, Hindell MA (2004) The diet of sperm whales (Physeter macrocephalus) in southern Australian waters. ICES J Mar Sci 61:1313-1329

Flood PR (1998) The skeletal muscle fibre types of Myxine glutinosa. In: Jorgensen JM, Lomholt JP, Weber RE, Malte H (eds) Biology of hagfishes. Chapman \& Hall, London, p 173-202

Forrest BM, Gillespie PA, Cornelisen CD, Rogers KM (2007) Multiple indicators reveal river plume influence on sediments and benthos in a New Zealand coastal embayment. NZ J Mar Freshw Res 41:13-24

Gaskin DE, Cawthorn MW (1967) Squid mandibles from the stomachs of sperm whales (Physeter catodon L.) captured in the cook strait region of New Zealand. NZ J Mar Freshw Res 1:59-70

Gaye-Siessegger J, Focken U, Muetzel S, Abel H, Becker K (2004) Feeding level and individual metabolic rate affect $\delta^{13} \mathrm{C}$ and $\delta^{15} \mathrm{~N}$ values in carp: implications for food web studies. Oecologia 138:175-183

Gómez-Villota F (2007) Sperm whale diet in New Zealand. Master of Applied Science, Auckland University of Technology

Graves GR, Newsome SD, Willard DE, Grosshuesch DA, Wurzel WW, Fogel ML (2012) Nutritional stress and body condition in the Great Gray Owl (Strix nebulosa) during winter irruptive migrations. Can J Zool 90:787-797

> Hatch KA, Crawford MA, Kunz AW, Thomsen SR, Eggett DL, Nelson ST, Roeder BL (2006) An objective means of diagnosing anorexia nervosa and bulimia nervosa using ${ }^{15} \mathrm{~N} /{ }^{14} \mathrm{~N}$ and ${ }^{13} \mathrm{C} /{ }^{12} \mathrm{C}$ ratios in hair. Rapid Commun Mass Spectrom 20:3367-3373

> Hobson KA, Alisauskas RT, Clark RG (1993) Stable-nitrogen isotope enrichment in avian-tissues due to fasting and nutritional stress: implications for isotopic analyses of diet. Condor 95:388-394

Hobson KA, Sirois J, Gloutney ML (2000) Tracing nutrient allocation to reproduction with stable isotopes: a preliminary investigation using colonial waterbirds of Great Slave Lake. Auk 117:760-774

Hoffman JC, Sutton TT (2010) Lipid correction for carbon stable isotope analysis of deep-sea fishes. Deep-Sea Res I 57:956-964

Hückstädt LA, Koch PL, McDonald BI, Goebel ME, Crocker DE, Costa DP (2012) Stable isotope analyses reveal individual variability in the trophic ecology of a top marine predator, the southern elephant seal. Oecologia 169: 395-406

Jaquet N, Dawson S, Slooten E (2000) Seasonal distribution and diving behaviour of male sperm whales off Kaikoura: foraging implications. Can J Zool 78:407-419

Johnson EW (1994) Aspects of the biology of Pacific (Eptatretus stouti) and Black (Eptatretus deani) hagfishes in Monterey Bay, California. Master thesis, Fresno California State University, CA 
Kiljunen M, Grey J, Sinisalo T, Harrod C, Immonen H, Jones RI (2006) A revised model for lipid-normalizing $\delta^{13} \mathrm{C}$ values from aquatic organisms, with implications for isotope mixing models. J Appl Ecol 43:1213-1222

Knapp L, Mincarone MM, Harwell H, Polidoro B, Sanciangco J, Carpenter K (2011) Conservation status of the world's hagfish species and the loss of phylogenetic diversity and ecosystem function. Aquatic Conserv Mar Freshw Ecosyst 21:401-411

Kolasinski J, Frouin P, Sallon A, Rogers K, Bruggemann HJ, Potier M (2009) Feeding ecology and ontogenetic dietary shift of yellowstripe goatfish Mulloidichthys flavolineatus (Mullidae) at Reunion Island, SW Indian Ocean. Mar Ecol Prog Ser 386:181-195

Korneliussen H, Nicolaysen K (1973) Ultrastructure of four types of striated muscle fibers in the atlantic hagfish (Myxine glutinosa, L.). Z Zellforsch Mikrosk Anat 143: 273-290

Lachenbruch PA, Mickey MR (1968) Estimation of error rates in discriminant analysis. Technometrics 10:1-11

Logan JM, Lutcavage ME (2008) A comparison of carbon and nitrogen stable isotope ratios of fish tissues following lipid extractions with non-polar and traditional chloroform/methanol solvent systems. Rapid Commun Mass Spectrom 22:1081-1086

> Logan JM, Jardine TD, Miller TJ, Bunn SE, Cunjak RA, Lutcavage ME (2008) Lipid corrections in carbon and nitrogen stable isotope analyses: comparison of chemical extraction and modelling methods. J Anim Ecol 77: 838-846

Lusseau SM, Wing SR (2006) Importance of local production versus pelagic subsidies in the diet of an isolated population of bottlenose dolphins Tursiops sp. Mar Ecol Prog Ser 321:283-293

Martini FH (1998) The ecology of hagfishes. In: Jorgensen JM, Lomholt JP, Weber RE, Malte H (eds) Biology of hagfishes. Chapman \& Hall, London, p 57-77

$>$ McConnaughey T, McRoy CP (1979) Food-Web structure and the fractionation of carbon isotopes in the Bering Sea. Mar Biol 53:257-262

McLeod RJ, Wing SR (2007) Hagfish in the New Zealand fjords are supported by chemoautotrophy of forest carbon. Ecology 88:809-816

Mellgren SI, Mathisen JS (1966) Oxidative enzymes, glycogen and lipid in striated muscle-a histochemical study in Atlantic hagfish (Myxine glutinosa (L)). Z Zellforsch Mikrosk Anat 71:169-188

> Peterson BJ, Fry B (1987) Stable isotopes in ecosystem studies. Annu Rev Ecol Syst 18:293-320

Pinnegar JK, Polunin NVC (2000) Contributions of stableisotope data to elucidating food webs of Mediterranean rocky littoral fishes. Oecologia 122:399-409

> Post DM, Layman CA, Arrington DA, Takimoto G, Quat-

Editorial responsibility: Hans-Heinrich Janssen,

Oldendorf/Luhe, Germany trochi J, Montana CG (2007) Getting to the fat of the matter: models, methods and assumptions for dealing with lipids in stable isotope analyses. Oecologia 152:179-189

> Powell ML, Kavanaugh SI, Sower SA (2005) Current knowledge of hagfish reproduction: implications for fisheries management. Integr Comp Biol 45:158-165

R Development Core Team (2012) R: A language and environment for statistical computing. www.R-project.org

Richardson LR, Jowett JP (1951) A new species of Myxine (Cyclostomata) from Cook Strait. Zoology Publications from Victoria University College 12:1-5

> Rodgers KL, Wing SR (2008) Spatial structure and movement of blue cod Parapercis colias in Doubtful Sound, New Zealand, inferred from $\delta^{13} \mathrm{C}$ and $\delta^{15} \mathrm{~N}$. Mar Ecol Prog Ser 359:239-248

Rogers KM (2009) Stable isotopes as a tool to differentiate eggs laid by caged, barn, free range, and organic hens. J Agric Food Chem 57:4236-4242

Rueda FM, Martinez FJ, Zamora S, Kentouri M, Divanach P (1998) Effect of fasting and refeeding on growth and body composition of red porgy, Pagrus pagrus L. Aquacult Res 29:447-452

> Shelton RGJ (1978) On the feeding of the hagfish Myxine glutinosa in the North Sea. J Mar Biol Assoc UK 58:81-86

> Smith CR (1985) Food for the deep-sea: utilization, dispersal, and flux of nekton falls at the Santa Catalina Basin floor. Deep-Sea Res I 32:417-442

Smith CR, Baco AR (2003) Ecology of whale falls at the deep-sea floor. Oceanogr Mar Biol Annu Rev 41:311-354

> Strahan R (1963) The behaviour of myxinoids. Acta Zool 44: 73-102

> Sweeting CJ, Polunin NVC, Jennings S (2006) Effects of chemical lipid extraction and arithmetic lipid correction on stable isotope ratios of fish tissues. Rapid Commun Mass Spectrom 20:595-601

Tamburri MN, Barry JP (1999) Adaptations for scavenging by three diverse bathyla species, Eptatretus stouti, Neptunea amianta and Orchomene obtusus. Deep-Sea Res I 46:2079-2093

- Tocher DR (2003) Metabolism and functions of lipids and fatty acids in teleost fish. Rev Fish Sci 11:107-184

Weatherley AH, Gill HS (1981) Recovery growth following periods of restricted rations and starvation in rainbow trout Salmo gairdneri Richardson. J Fish Biol 18:195-208

Zintzen V, Roberts CD, Anderson MJ, Stewart AL, Struthers CD, Harvey ES (2011) Hagfish predatory behaviour and slime defence mechanism. Scientific Reports 1:131, doi: 10. 1038/srep00131

Zintzen V, Anderson MJ, Roberts CD, Harvey ES, Stewart AL, Struthers CD (2012) Diversity and composition of demersal fishes along a depth gradient assessed by baited remote underwater stereo-video. PLoS ONE 7: e48522

Submitted: December 17, 2012; Accepted: March 13, 2013 Proofs received from author(s): May 27, 2013 